\title{
Konfiskace majetku českých Židů v poválečném Československu na př́kladu zámku a velkostatku Puklice
}

\author{
JAN KOUMAR*
}

\author{
Confiscation of the Czech-Jew Possession in the Post-war Czechoslovakia \\ Through Example of the Castle and Manor Farm Estate Puklice
}

\begin{abstract}
This study deals with the post-war confiscation of the possession of a Czech Jew Richard Fischmann, the last owner of the castle and manor farm estate Puklice in Czechoslovakia. Using the direct method of the archive document research, it tries to find the reasons why Fischmann was designated as a German despite the Nazi persecution of his whole family and his death in Auschwitz. The particular aim of this study is to set the whole event into the context of the relations between the last owner and Puklice village prior 1939, furthermore to try to find the causes leading to the subsequent post-war enmity and finally to extend the existing description of the whole confiscation process based on the Decree No. 12/1945 and its substantiation.
\end{abstract}

Keywords: Puklice; Jewish possession confiscation; post-war Czechoslovakia; Beneš Decrees, Czech Jews; accusation of germanisation; restitution disputes

DOI: $10.14712 / 23363525.2018 .51$

Židé vracející se na jaře roku 1945 do obnoveného Československa se nacházeli v nelehké situaci. Vraceli se se zkušeností s hrůzami koncentračních táborů, často ve špatném zdravotním i psychickém stavu, museli se smírit s tím, že jejich př́ibuzní i blízcí jsou ve většině př́padů mrtví. Vraceli se navíc do republiky okleštěné o Podkarpatskou Rus a k majetku, který v lepším či horším stavu museli za války opustit. Včetně optantů z Podkarpatské Rusi ${ }^{1}$ žilo jen v Čechách a na Moravě v roce 1945 asi 15000 Židů, ${ }^{2}$ z nichž se však $\mathrm{z}$ různých důvodů řada rozhodla $\mathrm{k}$ brzké emigraci. ${ }^{3} \mathrm{~K}$ té často nahrávaly majetkové poměry a otázka restitucí.

Zatímco před druhou světovou válku byla téměř třetina průmyslového a bankovního kapitálu Československa v židovských rukou, ${ }^{4}$ po válce byly na základě dekretů prezidenta republiky č. 100-103 hutě, doly, průmyslové podniky, banky i pojištovny znárodněny. $\mathrm{Na}$ zbytek majetku se sice vztahovala restituce, ${ }^{5}$ ta se nicméně stala problematickou, protože ji

* Mgr. Jan Koumar, Doktorský obor Aplikovaná etika, Fakulta humanitních studií, Univerzita Karlova, U Kř́rže 8, 15800 Praha 5. E-mail: jan.koumar@gmail.com.

1 Optanti byli ti Židé, kteří po připojení Podkarpatské Rusi k Sovětskému svazu optovali pro Československou státní príslušnost. Z 15-20 tisíc podkarpatských Židů to bylo okolo 5000 lidí [Čermáková 2009].

2 [Pěkný 2001: 348].

3 Např́ílad E. Beneš se na počátku roku 1946 vyslovil pro podporu sionistů a přislíbil možnost vystěhování se do Palestiny. Židé, kteří se však rozhodli zůstat, se podle Beneše museli zcela asimilovat, jinak by byli nuceni žít jako cizinci [Pěkný 2001: 349].

4 [Čermáková 2009].

5 Bliže a komplexněji k celému problému těchto restitucí viz Jančík, Kubư, Kuklik [2003]. 
v řadě př́padů komplikovala nenávist, závist, korupce i řady falešných obvinění. Pochybně slavný je v tomto ohledu tzv. varnsdorfský př́pad: konfiskace tkalcovny Emila Beera, který i když obdržel osvědčení o státní spolehlivosti a o státním občanství, svůj majetek zpátky nedostal: ONV ve Varnsdorfu namísto restituce zahájilo konfiskaci. Beer byl označen za aktivního germanizátora a na protest proti tomu, že by mu majetek mohl být vrácen, došlo ve městě ke stávce. ${ }^{6}$ Tento př́ípad však zdaleka nebyl jediný. V Mohelnici se restituce továrny marně dožadovali bratři Grätzové, kteří bojovali v západní armádě, v Žamberku byla zabrána továrna i vila z koncentračního tábora se navrátivších sester Nettlových. ${ }^{7}$

Ve stínu zmíněných slavných případů stojí restituční požadavek Fischmanových, dětí posledního majitele zámku a velkostatku v Puklicích. Puklice jsou drobná obec ležící $7 \mathrm{~km}$ od Jihlavy, svým přinejlepším jen regionálním významem jistě nepoutaly pozornost, puklický případ je však přesto zajímavý. Proslavil se především kvưli víc než dvacet let trvajícímu restitučnímu procesu, který zahájila dcera posledního majitele Eliška Fabryová (rozená Fischmannová) v roce 1990, během něhož rozjetý kolotoč vzájemných žalob, obviňování i hořkosti plnil četné, nejen regionální, deníky, a který se v listopadu 2001 dokonce objevil před Výborem Spojených národů pro lidská práva a rozhodnut byl teprve v roce 2012, kdy již samotná Fábryová byla šest let po smrti. Ve fiktivně upravené podobě měli čtenáři české beletrie možnost o případu číst v knize Radky Denemarkové, Peníze pro Hitlera. ${ }^{8}$ Vědecká pozornost případu př́liš věnována nebyla. Krom zmíněných článků v denících, jejichž kvalita byla kolísavá, se př́pad dočkal pouze krátkého, leč přehledného shrnutí ve Vlastivědném sborníku Vysočiny z roku $2008^{9}$ a několik článků opřených o dochované archiválie uveřejnil na serveru Regionalist jihlavský archivár̆ Ladislav Vilímek. ${ }^{10}$

Tato studie si proto klade za cíl puklický případ zabavení majetku Čechožida vykresleného účelově jako Němce zmapovat a na základě archivních materiálů jej uvést do širšího kontextu, což znamená především popsat vztah obce Puklice k majiteli velkostatku před rokem 1939 a v návaznosti na zmíněný text Silvie Čermákové z Vlastivědného sborníku Vysočiny shrnout možné příčiny, průběh i odůvodnění konfiskace proběhlé po květnu 1945.

\section{Puklice...}

Moravská obec Puklice má pouhých 645 obyvatel ${ }^{11}$ a v porovnání se sousední Jihlavou či Brtnicí není výrazně turisticky zajímavá. Katastrálně se dnes skládá ze tří dříve samostatných osad: samotných Puklic, Petrovic, ležících asi $2 \mathrm{~km}$ na severovýchod, a ze Studének, nacházejících se asi jeden kilometr severozápadně. Všechny tři obce neměly společný osud. Na rozdíl od Studének (Klein Studnitz) převážně české Puklice nespadaly

6 Více viz [Pěkný 2001: 372-374; Soukupová 2009].

7 [Čermáková 2009].

8 Brno: Host, 2006. Kniha byla v Čechách v roce 2007 oceněna Magnesií Literou, v Polsku v roce 2009 cenou Angelus a v podobě divadelní hry byla též uvedena v roce $2010 \mathrm{v}$ pražském Švandově divadle.

9 [Čermáková 2008].

10 Jedná se především o nedatovaný článek „Sága rodu Fischmannü“, dostupný z <http://www.regionalist.cz /vilimek/vil01_36.htm> a historii Puklic věnovaný (taktéž nedatovaný) článek Puklice, dostupný z $<$ http:// www.regionalist.cz/vilimek/vil01_2.htm>.

11 Stav k 1. 1. 2017 dle oficiálních webových stránek obce: <http://mujweb.cz/puklice>. 
do německy mluvícího Jihlavského jazykového ostrova, úzkého pásu na hranici Čech a Moravy, méříćího od severu k jihu zhruba $43 \mathrm{~km}$ a od východu na západ asi $18 \mathrm{~km} .{ }^{12}$ Vzdálenější Petrovice byly také s Puklicemi spojeny mnohem úžeji: jednak existencí tvrze, z níž bylo celé panství do vzniku tvrze v Puklicích rrízeno, ${ }^{13}$ jednak ale i existencí kostela a u něj ležícího hřbitova, který sloužil jako pohřebiště Puklických až do roku $1968 .{ }^{14}$ Alois Pátek ve svém oddíle Vlastivědy moravské o Jihlavském okresu odvozuje jméno Puklic od okolních malých vrchů, které podle něj připomínají poklice, ${ }^{15}$ nicméně tato etymologie je chybná. Název obce vznikl z majetkových vztahů: lokátorem byl muž jménem Pukl či Pukla, jméno tedy označuje ves, v níž bydleli Puklovi lidé.

\section{Zámek}

Historie Puklic začíná pravděpodobně koncem 13. století. Nejstarší zmínka o obci je z roku 1318, kdy Jan Lucemburský potvrzuje její zástavu Janovi z Řečice, do té doby byla spolu s Petrovicemi v majetku olomouckého biskupství. ${ }^{16}$ Snad již v té době vzniká v Puklicích tvrz, i když poprvé se písemně připomíná teprve v roce 1534, kdy ji Jan z Lipé propouští z léna jihlavskému měštanovi, nekatolíkovi Františku Hordarovi, který se začal psát s přídomkem z Puklice. Právě Hordarové tvrz přestavují v zámeček, k podsklepenému východnímu kř́́dlu ${ }^{17} \mathrm{v}$ roce 1578 navíc přistavují renesanční část. ${ }^{18} \mathrm{Za}$ účast ve stavovském odboji proti Ferdinandovi II. byly Hordarům dvě třetiny panství zkonfiskovány a rod musel přestoupit na katolickou víru, samotné Puklice ale drží až do roku 1666. Po Hordarech panství kupuje Jakub Manuel von Trümmel, za jehož panování k zámku přibylo barokní západní a jižní křídlo. Zámek se tak mění v čtyřkř̌ídlou budovu, z jejíhož východního kř́idla vystupuje arkýř na mohutném pilírí. Po Trümmlovi zámek sňatkem přechází do majetku Františka Josefa $\mathrm{z}$ Waderbornu, po němž jej roku 1731 zdědil František Adam Grisl z Grislova, po jeho smrti roku 1749 zůstává zámek jeho manželce. Od roku 1770 je majitelem Puklic rodina Malovcova, neplnoletému synovi Maxmiliány Malovcové však byly pro velké dluhy Puklice roku 1807 prodány a dostávají se do rukou Otty, svobodného pána Skrbenského z Hř́ště. Tehdy, počátkem 19. století, proběhly klasicistní úpravy zámku, dnes viditelné př̀edevším na fasádě. Skrbenského syn, také Otto, prodal puklické zboží roku 1878 batelovskému hraběti Karlu z Blankensteina. Blankensteinové jej drželi do roku 1893 , kdy velkostatek koupil majitel jihlavské továrny na škrob Miloslav Peška. ${ }^{19} \mathrm{~V}$ té době již zámek sloužil pouze jako správcovská budova statku a části přízemí byly využívány jako mlat pro blízký pivovar. V př́zemí východního křídla zámku existovala soukromá kaple

12 [Scheinhammer-Schmid 2013]. K tomu více viz [Hoffmann - Jaroš - Pisková - Svěrák 2000: mapový list č. 27]. V Puklicích žilo v roce 1921 právě 1021 obyvatel, z toho 958 Čechů, 58 Němců, 14 Židů. Viz <http://mujweb .cz/puklices.

13 [Jaroš 2004].

14 Teprve tehdy vzniklo nové pohřebiště prímo v obci.

15 [Pátek 1901: 207].

16 [Novák 1989: 2].

17 Podsklepení je zde spíše záležitostí reliéfu, zámek leží ve svahu, sklepy nejstaršího, východního křídla by tudíž z pohledu tohoto samotného kř́íla bylo možné brát jako přízemí, z pohledu celého zámku však leží pod úrovní terénu.

18 Což lze doložit letopočtem na dnes zazděném portále zámku v tomto severním kř́ídle.

19 [Pátek 1901]. 


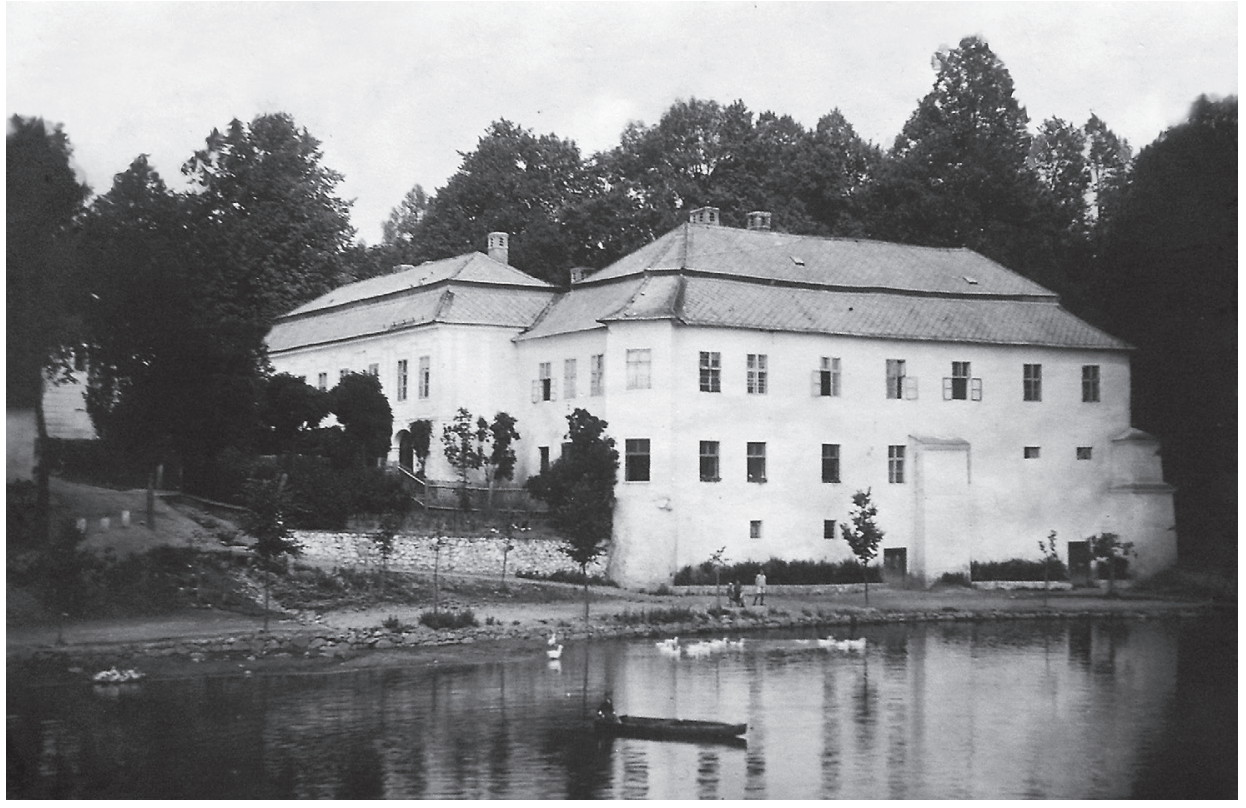

Obr. 1: Pohled na zámek Puklice od východu. Černobílá fotografie z 20. let 20. století (SOkA Jihlava, Neinventarizovaný fond, Kronika obce Puklice I., s. 134)

s oltářním obrazem Nanebevzetí Panny Marie. ${ }^{20}$ Mše se v kapli sloužily od roku 1729, za veřejnou byla prohlášena v roce 1787, za Malovcových v roce 1804 byla rozšířena. Továrník Peška ji v roce 1893 zrušil.

\section{Velkostatek}

Se zámkem souvisely hospodářsky cennější objekty velkostatku. Na severovýchodní straně zámeckého parku stála sýpka. Na jižní straně, naproti vchodu do zámku stával nejpozději od roku 1750 pivovar s vedle něj položeným bytem správce. ${ }^{21}$ Ke statku dále patřila i cihelna a škrobárna. K zámku přiléhal na severu velký park, drobný parčík se též nacházel na jižní straně pod okny kaple, za budovami statku ovšem ležela ještě zahrada s vlastním vodním zdrojem. K hospodářským účelům byl využíván i dnes již neexistující rybník ležící pod zámkem na Puklickém potoce. ${ }^{22} \mathrm{O}$ zahradu se staral zahradník ubytovaný v sousedství pivovaru, na jižní straně dvora leželo 6 stodol ${ }^{23}$ a k zámku konečně již na

20 [Ibid.: 207-208]. Srov. plán zámku v Puklicích, MZA v Brně, fond F379, Velkostatek Puklice 1770-1938, inv. č. 14, mapa 1. Oltář se zmíněným obrazem je na plánku situován k jižní stěně.

21 Viz Plán pivovaru v Puklicích, bytu správce a bytu zahradníka, ibid., inv. č. 19, mapa 6. Pivovar velmi pravděpodobně vznikl již dříve, Puklice ležely na hranici mílového práva, které chránilo monopol městských cechů, již koncem 17. století jsou doloženy spory s Jihlavou, kvưli pašovanému pivu z Beranova a Puklic [Vrána 2010].

22 MZA v Brně, fond Stabilní katastr - indikační skici (1824-1931), sign. MOR212918350.

23 Viz MZA v Brně, fond F379, Velkostatek Puklice 1770-1938, Plán stodol velkostatku v Puklicích, inv. č. 18, mapa 5. 
konci 19. století patřil i lihovar. ${ }^{24} \mathrm{~K}$ němu se sice dochoval plán, není však zcela jasné, kde stával, na lihovar byly nicméně v roce 1905 proměněny i budovy pivovaru po ukončení jeho provozu. V čele velkostatku stál správce, od roku 1798 kromě něj ještě myslivec a lesní a polní hajný. Účetní knihy podávají obraz dobrého hospodářství, velkostatek vzkvétal: v roce 1884 měli Blankensteinové v Puklicích 227,17 ha půdy, z toho 57,7 polí, 21,31 luk, zahrad 2,3, pastvin 6,92, lesů 123,35, rybníků 12,71. Co se živočišné produkce týče, v roce 1846 máme doloženo 7 koní, 10 kusů hovězího a 552 ovcí. ${ }^{25}$ Zatímco z mapování v roce 1835 vysvítá, že řada budov statku byla ještě dřevěných, na plánech z konce století již jsou všechny zděné.

\section{... a Židé}

Historii židovského osídlení na Jihlavsku se poměrně podrobně věnovali jiní autoři, ${ }^{26}$ omezím se proto pouze na krátké shrnutí. Vznik židovské obce v Puklicích lze datovat k roku 1426, kdy Albrecht Habsburský vypověděl Židy z Jihlavy. ${ }^{27}$ Ti pak odešli do okolních poddanských městeček, která ležela v docházkové vzdálenosti od Jihlavy. Puklický židovský hřbitov (na němž nejstarší náhrobek má být z roku $1421^{28}$ ) od té doby sloužil jako pohřebiště pro široké okolí, teprve s vybudováním nového židovského hřbitova v Jihlavě v roce 1869 jeho význam upadá. Puklická židovská obec byla nicméně nejmenší nejen na Jihlavsku, ale i na Moravě, ${ }^{29}$ v protikladu k Mikulovu (Nikolsburg), který měl přidělených 620 familiantských čísel, či k blízké Brtnici (Pirnitz) s 61 čísly, Puklice měly pouhých pět familiantů. ${ }^{30} \mathrm{Z}$ roku 1722 , za panství rodiny Malovcových, máme zprávu o puklické synagoze, znovu se o ní dozvídáme z roku 1842, nacházela se tehdy v patře domu čp. 35 . Kvůli poklesu členů židovské obce (v roce 1842 čítala 71 lidí, o necelé půlstoletí později pouhých 46) byla $\mathrm{v}$ roce 1891 zrušena a přičleněna $\mathrm{k}$ Jihlavě. ${ }^{31}$

Tam se Židům po roce 1848, kdy byly zrušeny familiantské zákony, ghetta a toleranční daň, otvírá svoboda usídlení. Prosincovou ústavou z roku 1867 pak získávají občanskou a politickou rovnost. ${ }^{32}$ To vedlo k růstu počtu obyvatel židovského vyznání ve městě. V letech 1862-1863 proto v Jihlavě vzniká reprezentační synagoga v maurském slohu, o čtyři roky později je založen židovský hřbitov a vznikají zde četné židovské spolky. Vznik Československa znamenal pro jihlavské Židy složitou situaci. Byli sice typicky západní židovskou komunitou, ${ }^{33}$ většinou byli spíše sekularizovaní a ortodoxie u nich byla spíše

24 Viz Plán lihovaru v Puklicích, ibid., inv. č. 20, mapa 7.

25 Inventární soupis fondu F379, s. 2.

26 Např. Jaroš [1994, 1998a, 1998b], Svěrák [1998], Pisková a kol. [2009].

27 Jaroš [1998a] akt vypovězení situuje již do podzimu 1424. Jihlava byla prvním moravským městem, které Židy vypovědělo, důvodem byla spolupráce Židů s tábority a tvrzení, že blízkost Židů a křestanů je pro křestany nebezpečná, nebot jsou díky ní vystaveni kacířským myšlenkám [Miller 2015: 27].

28 Náhrobek z tohoto data (5182 let od stvoření světa) zmiňuje Pátek [1901: 207] i Svěrák [1998], nicméně dnes je zřejmě neidentifikovatelný. Nejstarší doložený kámen je z roku 1699 [Svěrák 1998].

29 Stojí za zmínku, že zatímco v Čechách či v Rakouském Slezsku se přidělovala familiantská čísla podle krajů, na Moravě se přidělovala jednotlivým židovským obcím. To moravským Židům výrazně znesnadňovalo mobilitu. Více viz Miller [2015: 45-51].

30 [Miller 2015].

31 [Svěrák 1998].

32 [Pěkný 2001: 131n.].

33 Což znamená, že patřili ke střední a vyšší sociální vrstvě [Čapková 2005: 217-226]. 
vzácností. ${ }^{34}$ Jestliže ale československé Židy rozdělíme do třech hlavních skupin, česky mluvících, německy mluvících a sionistů, ${ }^{35} \mathrm{v}$ Jihlavě převažovala druhá skupina. Jihlavští Židé byli převážně nositeli německé kulturní orientace, díky čemuž byli také podezřívání ze styků s Němci a Madary proti republice. ${ }^{36}$ Snad právě proto byla integrace českých Židů do české menšiny v Jihlavě problémem, $\mathrm{z}$ důvodu jejího nezdaru v květnu 1919 vzniká Spolek českých Židů pro Českomoravskou vysočinu. ${ }^{37}$ Od dvacátých let počet Židů v Jihlavě klesá, stejný trend pokračuje celá léta třicátá.

\section{Poslední majitel zámku a velkostatku Puklice}

Vrat’me se však do Puklic, kde v roce 1905 zámek a velkostatek od továrníka Pešky koupil za 286000 korun $^{38}$ Siegfried Fischmann, člen puklické židovské obce. Fischmann sám se v Puklicích narodil, jeho žena Berta pocházela $\mathrm{z}$ Třebíče. Rodina měla jednu dceru, Malvine, a dva syny, Richarda, Huga. Když 13. 6. 1918 ve věku 71 let v jihlavské nemocnici Siegfried Fischmann zemřel, na puklickém statku již rok hospodařil jeho syn Richard. Mladší syn Hugo v té době vedl hospodářství na velkostatku ve Starči u Třebíče, se kterým byla rodina od roku 1865 spojena. ${ }^{39}$ Richard měl v té době již vlastní rodinu: manželku Ellu, dcery Ritu a Ellu (Elišku), rok po převzetí statku se mu měl narodit syn Vítězslav.

Na rozdíl od předchozích majitelů zámku a velkostatku Fischmannovi, jak se zdá, nebyli u místních obyvatel př́liš oblíbeni. Již sama skutečnost, že velkostatek vlastnili, nebyla Puklickým po chuti. Josef Šuhaj, pisatel místní kroniky, na několika místech povzdychává, že obec měla celý velkostatek již při vzniku republiky koupit či jednoduše zabrat, avšak liknavostí občanů tak neučinila, $\mathrm{z}$ čehož pramení řada obecních problémů. ${ }^{40}$ Důvodem neobliby ale nebyl pouze majetek: Fischmannovi nebyli totiž v obci jediní majetní; Ladislav Mareš, majitel továrny na kožené kabáty a oděvy, byl vedle velkostatku druhým abonentem jediné telefonní linky v obci ${ }^{41}$ a závisti se jistě také nevyhnul, přesto však byl od roku 1936 dokonce starostou. ${ }^{42}$ Zatímco však Mareš byl „Puklič́a“ a předchozí majitel velkostatku,

34 Českoslovenští Židé sice odmítali přestup ke křestanství, protože náboženství pro ně znamenalo základ kultury a existence jako skupiny, na druhé straně se však zvyky křestanské většině do značné míry přizpůsobovali [viz Petráš 2009: 349-351].

35 [Peroutková 2016: 24-25].

36 V samotné Jihlavě v roce 1910 žilo 25914 německy mluvících osob a pouhých 5210 česky mluvících osob. V o jedenáct let mladším sčítání se k české národnosti hlásilo 11581 osob, k německé 12887 osob a 1176 bylo jiné národnosti, z toho 488 Židů [Pisková a kol. 2009: 517].

37 Odůvodnění skutečnosti, že ustavení českého spolku iniciovali Židé z převážně německé Jihlavy, bylo založené právě na tom, že česká menšina ve městě nechce Židy do svých řad přijímat [viz Čapková 2005: 141-142].

38 [Vilímek 2016: 128].

39 Ve Starči zemřel Siegfriedův otec, narodil se tam sám Richard. V roce 1906 uvádí František Dvorský v Třebickém okresu Vlastivědy moravské Fr. Fischmanna jako nájemce místního panského dvora, polností i lihovaru [Dvorský 1906: 399].

40 SOkA Jihlava, Neinventarizovaný fond, Kronika obce Puklice I., s. 23, 34, 46.

41 Srov. SOkA Jihlava, Kniha 2. Zápisy ze schủzí obecního zastupitelstva, Zápis z 28. 3. 1934.

42 Jednalo se ale o dva velmi odlišné podnikatelské typy. Marešova firma prosperovala po celou dobu války, v roce 1945 zaměstnávala dokonce až 150 lidí. Pro kolaboraci s Němci byl proto Mareš v roce 1945 odsouzen $\mathrm{k}$ peněžité pokutě a vazbě na 1 rok. $\mathrm{V}$ roce 1949 proti němu byl proces obnoven a byl dán do pracovního tábora v Pardubicích a odsouzen ke ztrátě majetku. Po půl roce byl však propuštěn pro nemoc. Z konfiskátů z jeho firmy byla v roce 1949 přestavěna místní Sokolovna. Srov. SOkA Jihlava, fond MNV Puklice, Kniha 1, Zápisy ze schůzí pléna MNV, s. 231, 338; ibid., Neinventarizovaný fond, Kronika obce Puklice II., s. 77. 
z Jihlavy pocházející Čech M. Peška - „muž dobrého srdce, ale chvilkové nálady“43 - bydlel na zámku, Richard Fischmann se v roce 1923 odstěhoval do Jihlavy. V Žižkově ulici obýval dům č. p. 16. Již o rok později původní činžovní dům přestavuje ve výstavnou vilu, v níž ještě v roce 1936 nechává v prvním patře upravit šestipokojový byt s koupelnou, dvěma záchody a kuchyní, v dolním patře měl dva podnájemníky. ${ }^{44}$

Nepřítomnost majitele velkostatku byla jednak příčinou protahování řešení problémů, který provoz velkostatku obci přinášel: opakovaně byl písemně žádán o placení daní, zavodnění rybníka či o to, aby se dostavil na jednání obecní rady, ${ }^{45}$ navíc ale Puklickým dovolovala Fischmanna vybarvovat jako bezohledného podnikatele, který na svém majetku touží jen vydělat. Zatímco tedy na Pešku je s vděkem vzpomínáno jako na toho, kdo vysázel stromořadí ke kapličce v kopci nad obcí, ${ }^{46}$ a za zlé se mu nemá ani fakt, že nesnášel prozpěvování u sochy sv. Jana Nepomuckého a přikázal ji od zámku odstranit. ${ }^{47}$ Fischmannovi se vyčítá, že rozšíril statek, že parkem vozí brambory pro uskladnění a vystavěl v něm chlévy a že stáje pro dobytek postavil příliš blízko silnice na Jihlavu. ${ }^{48}$ Některá z těchto obvinění nejsou nepravdivá: o povolení stavby zdi stájí pouhé 3 metry od silnice žádal skutečně Fischmann Zemský úřad v Brně a stavba dodnes zasahuje do zákrutu silnice na Jihlavu, na druhé straně se mu však k dobru nepřičítají ani činy obci prokazatelně prospěšné, jako je stavba deputátních bytů, nová kolárna, kovárna či provoz lihovaru.

Právě lihovar, který vznikl již za Pešky přestavbou bývalého právovárečného pivovaru, se naopak stal významným důvodem neshod Fischmanna s obyvateli Puklic. Zatímco v blízké Želetavě či Brtnici vznikly do 20. let 20. století družstevní lihovary, ${ }^{49}$ ten puklický sloužil pouze statku, místní rolníci z něj neměli žádný užitek. Snažili se proto s Fischmannem vyjednat združstevnění, ten byl však v tomto bodě zcela neústupný. ${ }^{50} \mathrm{~V}$ roce 1925 , když všechny pokusy o vyjednávání selhaly, ujali se dva nejvlivnější pukličtí sedláci Karel Václavek a František Pauzar ${ }^{51}$ iniciativy za založení lihovaru družstevního. Jelikož však družstvo netvořili jen Pukličtí, ale i sedláci z okolních obcí (Stř́ižov, Studénky, Příseka, Přímělkov ${ }^{52}$ ) a jelikož Puklice neležely ve středu celé zájmové oblasti, bylo pro stavbu nového lihovaru vybráno místo od Puklic $2 \mathrm{~km}$ vzdálené, ležící v údolí Příseckého potoka při cestě na Stř́ížov. Lihovar vzdor své nevýhodné poloze hned po svém založení prosperoval, od počátku vyráběl větší množství lihu než Fischmannův konkurenční podnik, později $\mathrm{k}$ němu byla přistavěna suška na brambory, ještě později mlýn na obilí. Chod nového

43 SOkA Jihlava, Neinventarizovaný fond, Kronika obce Puklice I., s. 32.

44 [Vilimek 2016: 127].

45 K upomínkám k zaplacení daní viz: SOkA Jihlava, fond Obecní úřad Puklice, Kniha 5, Zápis ze schůze obecní rady ze 17. 5. 1930, z 31. 10. 1931 a další. K zavodnění rybníka viz ibid., Kniha 2. Zápisy ze schůzí obecního zastupitelstva, Zápis z 14. 7. 1934. K výzvám k dostavení se na schůzi obecní rady viz např. ibid., Kniha 5, Zápis ze schůze obecní rady, Zápis z 6. 7. 1934.

46 SOkA Jihlava, Neinventarizovaný fond, Kronika obce Puklice I., s. 165.

47 Ibid., s. 54.

48 Ke stavbě stájí viz SOkA Jihlava, fond Obecní úřad Puklice, Spis č. 45 Věci stavební, Protokol stavební komise z 15. 7. 31, k ostatním stížnostem viz Neinventarizovaný fond, Kronika obce Puklice I., s. 162, 180.

49 Viz MZA v Brně, fond H 1211, Družstevní lihovar Brtnice; MZA v Brně, fond H1263, Družstevní lihovar Želetava.

50 MZA v Brně, fond č. 3039, Družstevní lihovar Puklice, Inventární seznam.

51 Václavek byl v té době jmenován vládním komisařem v politicky rozhádaných Puklicích, Pauzar byl o rok později zvolen starostou obce.

52 Viz MZA v Brně, H1235, inv. č. 1, I.1/1 Seznam činovníků spolkových. 
lihovaru nenarušila ani válka, snad i proto, že četní členové představenstva byli Němci. ${ }^{53}$ Provoz Fischmannova lihovaru byl však od té doby obci trnem v oku. Připomíná se „smrdutý zápach" $\mathrm{z}$ jeho provozu, uložení škrabek $\mathrm{v}$ jámách vzniklých po kácení $\mathrm{v}$ zámeckém parku, pouštění odpadů $\mathrm{z}$ lihovaru a škrobárny do místního rybníka a tím opakované znečištování vod. ${ }^{54}$

Nutno také říci, že i když Fischmann zřejmě nebyl takový nelida, jak jej místní kronika chce líčit, šlo patrně o tvrdého podnikatele, ${ }^{55}$ který opakovaně otálel s placením obecních dávek, na výtky o znečǐštování vod vůbec nereagoval, a náprava mu často trvala neúnosně dlouho. ${ }^{56} \mathrm{I}$ listina podepsaná po válce bývalými zaměstnanci na Fischmannovu obranu neváhá připomenout, že šlo o člověka př́sného, který vyžadoval hodně práce, na své zaměstnance se často rozkř̌ikl a platil jen podle směrnic. ${ }^{57}$ Obecní úruad v podstatě nemajetných Puklic, které bojovaly s dluhy ${ }^{58}$ a po zámku s velkostatkem závistivě pošilhávaly, bral Fischmann často přezíravě. ${ }^{59} \mathrm{~V}$ obci s velkým počtem bezzemků navíc jistě nezůstalo bez povšimnutí, že byl Richard Fischmann podnikatelsky velmi schopný: celková výměra půdy statku se zvětšila o 40 hektarů, ubylo lesů, vzrostla však výměra polí. ${ }^{60} \mathrm{Na}$ zahradě statku postavil Richard skleník, nedaleko Puklic při cestě na Petrovice vznikla nová hájovna. ${ }^{61}$ Snažili-li se pukličtí občané Fischmannovo podnikání omezit, velkou př́ležitost jim k tomu navíc v roce 1925 nedala pozemková reforma mladého Československa. Bylo jí sice podrobeno 284,4 hektarů veškeré půdy, $\mathrm{z}$ toho bylo 178,73 zemědělské, přes požadavky na parcelaci velkostatku ovšem drobní nabyvatelé dostali pouze 20 hektarů zemědělské půdy, ${ }^{62}$ zbytek byl Fischmannovi propuštěn zpět ze záboru. To kronika obce neopomíná přič́st liknavosti obyvatel a prohnanosti velkostatkáře. ${ }^{63}$

Na druhé straně Fischmann nepracoval pouze pro sebe, kvůli neschopnosti obecní rady však jeho nabídky zůstávaly nevyužity. Tak např́klad v době, kdy do záboru spadající místnosti v zámku byly používány jako tělocvična Sokola, nabídl zdarma dodat dřevo na stavbu Sokolovny, obci to však nestačilo, požadovala po něm navíc ještě půjčku v hodnotě

53 MZA v Brně, fond č. 3039, Družstevní lihovar Puklice, Inventární seznam.

54 SOkA Jihlava, fond Obecní úřad Puklice, Kniha 4, Zápis ze schůze obecní rady 28. 5. 1932; ibid., Neinventarizovaný fond, Kronika obce Puklice I., s. 180.

55 Když např́iklad 2. 2. 1925 František Pauzar žádal o obecní podporu pro chudou K. Literovou, neopomněl do zápisu dodat, že zdejší velkostatkář žádnou almužnu chudému nedá (SOkA Jihlava, fond Obecní úřad Puklice, Kniha 2., s. 38-40).

56 K neplacení dávek srov. SOkA Jihlava, fond Obecní úřad Puklice, Kniha 4, Zápis z 14. 7. 1934. Srov. ibid., Kniha 4, Zápis ze schůze obecní rady 25. 8. 1932, 19. 6. 1932. Čistička byla konečně zkolaudována v říjnu 1936. Viz ibid., Kniha 6, Protokoly obecní rady, s. 8.

57 SOkA Jihlava, fond JNV Jihlava, inv. č. 133, Konfiskáty, Prohlášení z 10. 8. 1945.

58 Viz SOkA Jihlava, fond Obecní úřad Puklice, Kniha 5. Ještě v roce 1946 po konfiskacích se obec popisuje jako chudá (SOkA Jihlava, fond MNV Puklice, Spisy, inv. č. 73 Konfiskáty, Žádost o přidělení budovy bývalého lihovaru v Puklicích).

59 Př́kladem může být Horní (tzv. zámecký) rybník, který Fischmann vypustil a byl upozorněn na fakt, že k jeho vypuštění a tím odstranění rezervoáru vody pro hasiče potřebuje souhlas obce (SOkA Jihlava, fond Obecní úrud Puklice, Kniha 5, Zápis obecní schůze z 14. 7. 1934). O čtyři roky později tedy Fischmann o povolení požádal, aniž by však na něj čekal, rybník znovu ihned vypustil (ibid., fond MNV Puklice, Kniha 1, Zápisy ze schůzí pléna MNV, Zápis ze schůze z 23. 7.1938).

60 Srov. MZA v Brně, fond F379, Velkostatek Puklice 1770-1938, inventární soupis.

61 SOkA Jihlava, fond Obecní úřad Puklice, Spis č. 45 Věci stavební, Plán na postavení hájenky na parcele 1028/1 březen 1937

62 MZA fond F379, Velkostatek Puklice 1770-1938, inventární soupis. Stránky obce uvádí pouhých 15 ha.

63 SOkA Jihlava, Neinventarizovaný fond, Kronika obce Puklice I., s. 23. 
30000 Kč a stavební parcelu v zámeckém parku. Ze stavby tudíž sešlo a plánovaná Sokolovna se pak bezvýsledně projednávala ještě řadu let. ${ }^{64} \mathrm{~V}$ prostorách zámku dovolil umístit poštovní úřad, který se do té doby tísnil v prostorách staré školy. Na zámku získala také prostory poradna pro matky, i když upravit a přizpůsobit si je musela sama obec. ${ }^{65}$ Obec navíc měla k velkostatkáři rozporný vztah, na jednu stranu jakoby jej stále považovala za vrchnost odpovědnou za vše, zároveň se mu ale cítila nadřazena. Od Fischmanna se tedy například očekávala oprava obecní cesty, přispění na opravu parčíku ve středu obce u sochy sv. Jana či držení obecního býka pod cenou. ${ }^{66}$ Zároveň mu ale obec vyčítá rozšiřování statku i fakt, že neopravuje obecní lávku přes Horní rybník (pod zámkem), která byla nicméně v obecním majetku. ${ }^{67}$ Rozpačitost obecní rady dokumentuje i fakt, že když se jedná o staré lidi, kteří byli u Fischmanna po celý život zaměstnáni a které statkář nutí, aby se jakožto práce neschopní na stará kolena vystěhovali, obecní rada sice situaci prodebatovala, ale „k nijakému rozhodnutí nedošla“. 68

\section{Válečné osudy Fischmannů}

Když 15. 3. 1939 začaly v Protektorátu platit norimberské zákony, dochází k četným bouřím. Dne 30. 3. 1939 byla vypálena synagoga v Jihlavě, zničena byla o týden později i obřadní síň hřbitova a povalena většina tamních náhrobků. ${ }^{69}$ Fischmannovi byli již tři dny před bouřemi, které ve zničení synagogy vyústily, z pobytu ve své jihlavské vile přesunuti do Puklic, ${ }^{70}$ vila byla spolu s dalšími domy po vystěhovaných Židech použita k ubytování př́íchozích Němců a nových institucí. Dcera Rita byla v té době již provdána v Telči za MUDr. Böhma, dcera Eliška, provdaná Kosková, žila v Praze. S Richardem a Ellou Fischmannovými tak v té době žil jen tehdy dvacetiletý syn Vítězslav, který ve školním roce 38/39 dokončil studia na českém gymnáziu, kde byl v třídních knihách zapsán s českou národností, československou státní příslušností a židovským vyznáním. ${ }^{71}$ Po přesunu z Jihlavy rodina nejprve bydlela na zámku, záhy se však přestěhovala do nedávno dostavěné hájenky u panského lesa, aby nebyli na očích nacisticky nejagilnější rodině komisaře Lopaty. ${ }^{72}$ Zatímco byl Fischmannův puklický majetek arizován a na Puklice byla uvalena nucená správa, kterou až do roku 1945 vykonával U. Rokahren, ${ }^{73}$ Fischmannovi se stěhují do Telče, kde v židovském ghettu na tehdejší Nádražní, dnes Masarykově ulici bydlí až

64 Ibid., s. 45, 46, 148. Srov. SOkA Jihlava, fond Obecní úřad Puklice, Kniha 2. Zápisy ze schůzí obecního zastupitelstva, Zápis z 18. 1. 1930.

65 Ibid., Kniha 6, s. 47.

66 K opravě obecní cesty: SOkA Jihlava, fond Obecní úrrad Puklice, Kniha 2. Zápisy ze schůzí obecního zastupitelstva, Zápis ze 17. 4. 1933 K údržbě parčíku: ibid. K obecnímu býkovi: ibid., Kniha 5, s. 67, 111. Fishmannovi obec platila za držení býka 4000,- Kč ročně, opakované žádosti o zvýšení této částky zamítala, když na sebe držení býka vzal v roce 1941 Karel Václavek, byl za něj honorován částkou 8500,- Kč (ibid., fond MNV Puklice, Kniha 1, s. 98).

67 K obecní lávce: ibid., s. 35, 40 (leden a únor 32).

68 SOkA Jihlava, fond MNV Puklice, Kniha 1, Zápisy ze schůzí pléna MNV, Zápis o schůzi z 19. 6. 1937, s. 32.

69 [Jaroš 1998b].

70 [Vilímek 2016: 127].

71 [Čermáková 2008].

72 SOkA Jihlava, Neinventarizovaný fond, Kronika obce Puklice I., s. 392.

73 Archivní prameny nesdělují mnoho detailů o jednotlivých arizátorech, o nacisticky agilní rodině komisaře Lopaty se zmiňuje Kronika (SOkA Jihlava, Neinventarizovaný fond, Kronika obce Puklice I., s. 392), o osudu údajně dochovaných úředních knih viz níže. 


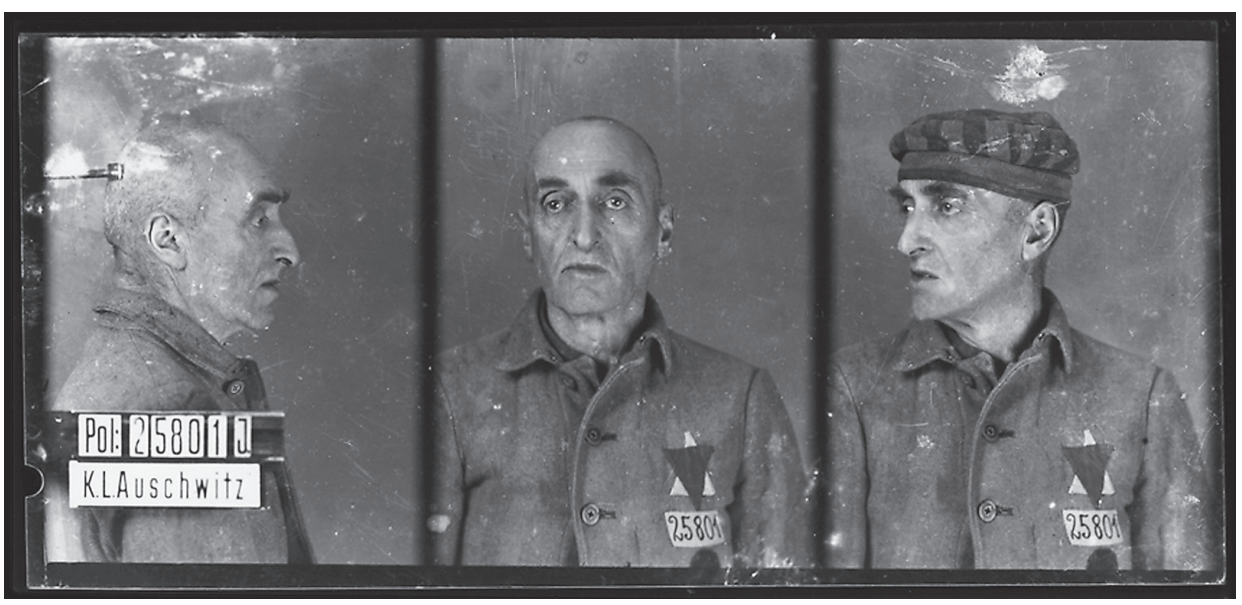

Obr. 2: Richard Fischmann jako vězeň v koncentračním táboře Osvětim (archivní sbírka Státního muzea Auschwitz-Birkenau v Oświęcimi, publikováno s povolením SM Auschwitz-Birkenau v Oświęcimi)

do roku 1942, kdy jsou povoláni do sběrného střediska v Třebíči a po registraci jdou do transportu Aw do Terezína.

Sám Richard Fischmann byl však již v roce 1941 v Telči zatčen, uvězněn nejprve v Jihlavě, později v Kounicových kolejích v Brně, odkud byl deportován do Osvětimi, kde 11. 2. 1942 ve věku 62 let zemřel. ${ }^{74}$ Jeho o sedm let mladší žena Ella byla 22. 5. 1942 z Telče odvezena do Terezína a odtud 23. 10. 1944 do Osvětimi. Syn Vítězslav byl do Terezína deportován se svou matkou, 28. 9. 1944 byl pak odvezen do Osvětimi. ${ }^{75}$ Odtud se mu ovšem v lednu 1945 podařilo uprchnout, dostal se do Košic k armádě generála Svobody, v níž se v hodnosti vojína aspiranta dočkal konce války a osvobození Československa. ${ }^{76}$ Rita Fischmannová, provdaná Böhmová, 28letá zdravotní sestra, byla odvezena nejprve do Terezína, 23. 10. 1944 pak do Osvětimi, ${ }^{77}$ kde zemřela, její manžel zemřel v Dachau. Druhá dcera Eliška, provdaná Kosková, přežila vězení v Terezíně. Krátce po Richardovi, 11. 6. 1941, zahynul v Osvětimi i židovský správce velkostatku Robert Birnbaum, zatčený v Puklicích za údajné držení zbraně. Ze 1350 osob odvlečených z Jihlavska do koncentračních táborů pouhých 32 holokaust př̀žilo ${ }^{78}$

\section{Konfiskace}

Židé, kteří válku přežili, se po svém návratu často dočkali nepříjemných překvapení. „Vraceli se do společnosti, která o ně nestála, neočekávala je a nebyla na ně připravena ani

\footnotetext{
74 Viz data $z$ databáze <https://www.ushmm.org/online/hsv/person_view.php?PersonId=6880153>, číslo vězně 25801.

75 [Jaroš - Zimola 1998].

76 SOkA Jihlava, fond JNV Jihlava, inv. č. 133, Konfiskáty, Odvolání proti vyhlášce ONV z 11. 7. 1945.

77 [Jaroš - Zimola 1998].

78 [Šimka 1958: 58].
} 
materiálně, ani mentálně. “79 Mnozí z nich našli své domy obsazené Čechy, a i když existovaly výjimky, majetek, který před odchodem svěřili známým nebo sousedům již zpátky nedostali. ${ }^{80}$ Puklice reagovaly na novou situaci rychle. Velkostatek byl do Národní správy převzat 26. 5., nucená správa na velkostatku byla však kupodivu zrušena až 3. 8. 1945, již 11. 7. 1945 ale padlo na ONV Jihlava rozhodnutí o konfiskaci na základě dekretu prezidenta republiky 12/1945 Sb. MNV Puklice dále již 20. 7. téhož roku, tedy ještě za trvání nucené správy, vyzval k podání žádostí o př́iděl konfiskované půdy. ${ }^{81}$ Projednávání budoucí parcelace však začalo ještě dříve. Místní národní výbor (dále jen MNV) poprvé řešil budoucí rozdělení pozemků již na počátku července a od té doby se již také objevovaly žádosti o poskytnutí bytu v budově zámku či o pronájem rybníku. ${ }^{82}$ Přeživší Fischmannovi se nicméně bránili. Když bylo Vítězslavovi 21.7. doručeno rozhodnutí ONV, oba sourozenci proti konfiskaci podali prostřednictvím advokáta Františka Torše námitky a rozklad, v němž se podivují, že dekret prezidenta republiky o majetku Němců, Mad’arů a zrádců českého a slovenského národa mohl být podkladem ke konfiskaci velkostatku jejich otce, který byl Čech. Nikdy nevedl politický život, zabýval se jen hospodařením, své děti v převážně německé Jihlavě posílal do českých škol, byl obětí politické a rasové perzekuce a nakonec zemřel v Osvětimi. ${ }^{83}$

Puklice se však už $\mathrm{k}$ parcelaci velkostatku zjevně rozhodly a k námitkám se mínily vyjádřit po svém. Poslední den v srpnu 1945 rolnická komise a MNV vedené předsedou Karlem Tesařem vydává memorandum, v němž ohlašují, že se splnil dávný sen a zbožné přání puklických občanů a dekretem prezidenta osvoboditele patří velkostatek v Puklicích opět do českých rukou, nebot' i poslední majitel sice mluvil česky, ale smýšlením byl Němec. Po třech stech letech tak budou konečně odčiněny křivdy napáchané na české rodině Hordarů, kteří stáli proti Habsburkům, a proto jim byl majetek germanizován. ${ }^{84}$ Takové prohlášení na puklické občany jistě působilo motivačně. Přesto na dvacet bývalých zaměstnanců velkostatku podepsalo listinu, která Fischmanna sice nelíčí jako anděla, ale potvrzuje, že byl Čech, se všemi zaměstnanci mluvil česky a obec nejen negermanizoval, ale $\mathrm{v}$ př́ípadě Sokolovny jí dokonce vyšel vstříc.

Již 23. 7. 1945 vydal také statistický úřad osvědčení o národnosti, v němž potvrzuje, že se Fischmann při sčítání v roce 1930 hlásil k národnosti židovské. ${ }^{85}$ To bylo významné, rovnou do odsunu byli totiž po svém návratu zařazováni německy mluvící Židé, mnozí z nich si proto později počeštili svá jména. ${ }^{86}$ Získání českého občanství bylo podmíněno národností, k níž se dotyčný hlásil při sčítání lidu v roce 1930, kdo se hlásil k německé národnosti, byl za Němce považován. Kromě faktu, že nebyl Němec, muselo být o zemřelém Richardovi Fischmannovi prokázáno, že nebyl aktivním germanizátorem. ${ }^{87}$ Germanizací se pak konkrétně rozuměla „mimořádná a soustavná podpora němectví mezi Slovany,

79 [Peroutková 2016: 79].

80 [Ibid.: 81].

81 SOkA Jihlava, fond JNV Jihlava, inv. č. 133, Konfiskáty, Vyhláška MNV z 20. 7. 1945.

82 Ibid., s. 142, Zápis z 3. 7. 1945; ibid., s. 143, Zápis z 23. 7. 1945

83 Ibid., Odvolání proti vyhlášce ONV z 11. 7. 1945.

84 Ibid., Memorandum z 31. 8. 1945.

85 Ibid., Osvědčení o národnosti č. j. B-2193/13397-15-2.39.

${ }^{86} \mathrm{Z}$ nejznámějších lze jmenovat Ottu Pavla, původně Poppera, spisovatele Norberta Frieda (který se stal Frýdem) a Martina Reacha (který se stal Janem Martincem) [Peroutková 2016: 82].

87 Autorem návodu, jak jedince obvinit z germanizace byl ministr vnitra Václav Nosek, který návod rozesílal nižším úřadům státní správy [Soukupová 2009]. 
a to nejen v meziválečném období, ale i dřive, jako zakládání a podpora německých škol, společenských a kulturních zařízení, odnárodňovací tlak na příslušníky slovanských národů v zaměstnání“ 88

O údajných předválečných germanizačních snahách Fischmannů nás přitom nenechává na pochybách rezoluce místní rolnické komise i druhý díl Kroniky obce Puklice. Tam, kde v prvním díle kronikář jen povzdechuje nad tím, že velkostatek není majetkem obce, v druhém díle je Fišman (sic!) obviněn z aktivního germanizátorství. Je sice popsán jako Čech, avšak smýšlením Němec, který se správci statku německy komunikoval, německy vedl účetnictví a podporoval německé školy. Přítěží se mu stává všechna jeho dřivější podnikatelská tvrdost: vykořistoval deputátní lid, hanebně nakládal s těhotnými ženami, obecní rybník otravoval kalem, rozjezdil obecní cestu, odmítl přispívat na kostel v Petrovicích, kde se lid česky modlil k Bohu. V pěkné budově zámku skladoval pouze výpalky z lihovaru, Sokol nechal tísnit se v několika místnostech, místo aby mu dal celé patro zámku, o jeho hamižnosti svědčí i fakt, že nezdružstevnil lihovar a odmítl prodat velkostatek přes několik jednání s obcí. ${ }^{89}$

Tato závažná obvinění ovšem nejsou bez disonancí. „Pěknému“ zámku obec sama v žádosti o jeho převedení do svého majetku název zámek upírá, je prý za něj považován neprávem: jde pouze o větší, starou budovu. ${ }^{90}$ Lihovar se škrobárnou - dle poválečné inspekce zcela schopné obnovení provozu ${ }^{91}$ - jsou uzavřeny, zařízení rozprodáno do okolních lihovarů a budova sama je nejprve parcelována na byty, aby později byla tato parcelace zrušena a celý lihovar byl nakonec předán Sokolu. Zadluženost Puklic spolu se zápisy z jednání obecní rady a údaji z prvního dílu kroniky zjevně popírají, že by obec někdy byla od Fischmanna schopna velkostatek vykoupit. ${ }^{92}$ Poslední správce statku R. Birnbaum, je jen o stránku dříve ve vzpomínce na jeho hrdinnou smrt pochválen jako Čech, „muž sociálního cítění, uhlazených způsobů a veselé mysli“, 93 jeho vdova navíc i za přítomnosti příslušníků SNB potvrdila, že s Fischmannem korespondoval i mluvil česky. ${ }^{94} \mathrm{Z}$ koncentračního tábora se navrátivší bývalý vedoucí Židovské náboženské obce (dále jen ŽNO) v Jihlavě Karel Meisel dokonce napsal na potvrzení Fischmannova češství ministru Noskovi. ${ }^{95}$ Bývalý správce statku do roku 1928 Dominik Blecha potvrzuje, že Fischmann mluvil česky, dával peníze na dobročinné účely a byl dobrým zaměstnavatelem. ${ }^{96}$ Českou mluvu i štědré příspěvky potvrzují i tři další přeživší členové jihlavské ŽNO. ${ }^{97}$

Tváří tvář takovým důkazům i námitkám proti konfiskační vyhlášce přeživších Fischmannových, které z Brna ohlásil Dr. Šrubař, ${ }^{98}$ muselo zřejmě MNV Puklice přitvrdit,

88 [Staněk 1991].

89 SOkA Jihlava, Neinventarizovaný fond, Kronika obce Puklice II., s. 13-17; ibid., fond JNV Jihlava, inv. č. 133, Konfiskáty, Resoluce ze 4. 10. 1945.

90 MNV Puklice, Spisy, inv. č. 73 Konfiskáty, Dopis ze dne 2. 12. 1946; ibid., Žádost o přidělení budovy zámku a přilehlého parku v Puklicích ze dne 14. 12. 1946.

91 Srov. ibid., Likvidace nár. správy velkostatku v Puklicích, Zápis o služební cestě 11. 7. 1946.

92 SOkA Jihlava, Neinventarizovaný fond, Kronika obce Puklice I., s. 23, 34, 45, 148; ibid., fond Obecní úřad Puklice, Kniha 5, Protokol o schůzích obecní rady v Puklicích. 22. 1. 1934 - 22. 8. 1936.

93 SOkA Jihlava, Neinventarizovaný fond, Kronika obce Puklice II., s. 12.

94 SOkA Jihlava, fond JNV Jihlava, inv. č. 133, Konfiskáty, Protokol z 16. 10. 1945.

95 Ibid., složka dopisy, Meisel Karel ONV v Jihlavě.

96 Ibid., složka dopisy, Prohlášení.

97 Ibid., Potvrzení ŽNO z 12. 8. 1945.

98 Ibid., Protokol, č. j. 666/P/IV V. 
v obci se již o budoucí parcely na zkonfiskovaném majetku přihlásilo 87 jednotlivců a 3 družstevní organizace. ${ }^{99}$ Dne 31. 8. 1945 odpovídá předseda Tesař jihlavskému ONV na dotaz, na základě čeho byl statek zkonfiskován. Opakuje všechna předchozí tvrzení (Fischmann mluvil německy s účetním Kohnem, nepřispíval na české sbírky, neopravil cesty a vymlouval se přitom na placení daní, ...) přitvrzuje ale v líčení jeho asociálního chování: „Deputátním ženám nadával tak sprostě (...) svině, kurvy, nakopu vám do držky (...), mužům nadával rovněž, volů, blbců, zlodějů, lenochů. “100 Navíc však udává, že i když všechny spisy na zámku zničila Rudá armáda, dochovala se na důkaz Fischmannova němectví jedna německy psaná kniha. O jejím získání nás informuje kronikár. Když Dr. Šrubař na pozemkovém referátě v Brně kladl puklickým na srdce, že je potřeba doložit Fischmannovo němectví, „předseda Tesař, Neubauer a další se nedali tím odstrašiti. Pátrali po knihách a našli je v jednom domku v Saulerindle, kde si s nimi hrály děti, když je rodiče náhodou přinesli ze zámku. A tyto knihy, německy psané, stačily okresní komisi. "101 ONV se na schůzi 21.9. rozhodla, aby se parcelace urychleně provedla. ${ }^{102}$

Stran německých knih máme ovšem informací více. Fischmannovi dědicové se za prvé odvolávají proti tvrzení, že by zmíněným způsobem nalezená Wirtschaftbuch z let 1938/39 vůbec byla knihou puklického velkostatku a že by jí tedy bylo možné použít jako svědectví otcova němectví. ${ }^{103} 18.10 .1945$ se navíc v protokolu sepsaném při projednávání námitek proti konfiskaci tvrdí, že existuje: „Hlavní účetní kniha od roku 1920 psaná německy, pouze s několika zápisy českými v roce 38 , kniha mezd vedená jen německy, hospodářská kniha pro rok 38-39 vedená na německých tiskopisech a německy, hlavní kniha $\mathrm{z}$ roku 37-38 na německých tiskopisech a německy. "104 $\mathrm{O}$ rok později se však při likvidaci národní správy zjištuje, že účetní knihy a záznamy přecházející ustanovení NS „byly válečnými událostmi zničeny nebo jinak zašantročeny“. 105 Přihlédneme-li k nouzi o důkazy Fischmannova němectví, kterou zmiňuje kronikář, lze o tom, že zmíněné účetní a hospodářské knihy s tiskopisy vůbec kdy existovaly, důvodně pochybovat.

Bývalí zaměstnanci velkostatku, kteří v srpnu 1945 podpisy podpořili prohlášení o Fischmannově češství také představovali významnou kartu v ruce proti konfiskaci protestujících dědiců. Za přítomnosti předsedy Tesaře a zapisujícího příslušníka SNB si proto 3. 10. na MNV Puklice většina $\mathrm{z}$ nich vzpomíná, že pưvodní prohlášení o Fischmannově češství podepisovali v kanceláři ve dvoře, kam je volal bývalý správce Jaroslav Vaněk a že k podepsání je sice nikdo nenutil, když jim však nyní bylo vysvětleno, o co vlastně šlo, své podpisy musí odvolat. Většina z nich stále tvrdí, že Fischmann byl Čech, odvolávají však tvrzení, že nebyl asociální a že dal před válkou Sokolu prostory v zámku, protože o tomto darování nemají podrobné informace. ${ }^{106}$ Při následném výslechu na stanici SNB si navíc někteří z podepsaných začínají vybavovat, že Fischmann mluvil s někým či alespoň se

\footnotetext{
99 SOkA Jihlava, fond JNV Jihlava, inv. č. 132, Velkostatek Fischmann, karton 33.

100 SOkA Jihlava, fond JNV Jihlava, inv. č. 133, Konfiskáty, č. j. 193.

101 SOkA Jihlava, Neinventarizovaný fond, Kronika obce Puklice II., s. 17.

102 SOkA Jihlava, fond JNV Jihlava, inv. č. 133, Konfiskáty, č. j. 193.

103 Ibid., č. j 1514-VIII/28-45.

104 Ibid., Protokol ze dne 18. 10. 1945.

105 Ibid., Zápis o služební cestě.

106 Ibid., Protokol z 3. 10. 1945.
} 
svou rodinou německy. ${ }^{107}$ Sám správce Vaněk, tváří v tvář obvinění, že to byl on, kdo bývalé zaměstnance k podepisování svolal, tvrdí, že prohlášení psal v kanceláři velkostatku Vítězslav Fischmann a jeho sestra Eliška mu jej diktovala. Dodává, že někteří zaměstnanci podepsali bez předchozího přečtení, ${ }^{108}$ čímž jejich svědectví v podstatě shazuje ze stolu.

I když někteři i na úřadovně SNB ještě nepřestávají potvrzovat češství bývalého velkostatkáře, ${ }^{109}$ obec při projednání námitek proti konfiskaci opakuje svá tvrzení o německy psaných knihách a dodává, že Fischmann se všemi správci mluvil pouze německy. Statistickým úřadem vydané potvrzení o Fischmannově české národnosti odsouvá stranou s tím, že se celá rodina při sčítání díky propagační akci sionistů neměla odvahu přihlásit k německé národnosti a dokonce přichází s tvrzením, že byl Fischmann v letech 1938-1939 členem NSV. ${ }^{110} \mathrm{I}$ když poslední, téměř skandálně působící tvrzení v rozhodnutí Zemského národního výboru z 20. 3. 1946 chybí, Fischmannova německá národnost i cítění se považují na základě svědectví za prokázané a proto se námitky zamítají a konfiskace se nařizuje s okamžitou platností. ${ }^{111}$

Rozhodnutí ONV v Jihlavě sice s konečnou platností potvrzuje teprve Nejvyšší správní soud v Bratislavě 3. 12. 1951, to však již byl velkostatek s lihovarem a zámkem oceněný v roce 1946 na 4006821 korun 20 haléřů dávno rozparcelován. Již na konci ř́ina totiž zástupci ZNV v Brně a ONV v Jihlavě předsedu MNV ujistili, že na základě dokladů o německé národnosti bývalého majitele se parcelace provádět bude. ${ }^{112}$ Budovu bývalého lihovaru, v němž již provoz nebyl obnoven, získává po delších tahanicích Sokol, z peněz získaných konfiskací firmy Mareš ${ }^{113}$ si v ní upravil Sokolovnu, používanou později i jako kino. ${ }^{114}$ Bývalou sýpku na severozápadním konci zámeckého parku Kostelní jednota přestavěla v kostel. Zámek dostal v roce 1947 po opakovaných žádostech do majetku MNV Puklice, ${ }^{115}$ část použil pro své úřadovny, část prvního patra byla přestavěna na byty, garáže dostala hasičská zbrojnice, místnost byla též přidělena Jiráskově knihovně a poradně pro matky. Co se však zámeckého inventáře týče, již v roce 1945 se při převzetí zámek ukazuje být zcela vydrancovaný. Většina měla být zlikvidována za Rokahrova správcovství, ostatek byl zlikvidován př́íchodem Rudé armády. Ztratily se vozy, automobily, válečné škody se odhadují na 1,3 miliony korun. ${ }^{116}$ Ze zbylého inventáře máme v závěru roku 1946 doloženou nikým nepoužívanou koupací vanu, ${ }^{117}$ v závěru roku 1953 byl pak ze zámku do sběrny

107 Bývalý zahradník Benda tvrdí, že Fischmann mluvil s adjunktem, správcem a účetním pouze německy (ibid., Protokol sepsaný na SNB s Antonínem Bendou 3. 10. 1945), Václav Konhefr o dva týdny později již na SNB potvrzuje, ve Fischmannově rodině se mluvilo výhradně německy a že vedl dvojí účetní knihy, aby nemocenské pojištovně mohl hlásit menší dělnické platy (ibid., Protokol s Václavem Konhefrem sepsaný na SNB 15. 10. 1945).

108 SOkA Jihlava, fond JNV Jihlava, inv. č. 133, Konfiskáty, Dodatek protokolu sepsaného dne 3. 10. 1945.

109 Ibid., Protokol sepsaný 3. 10. 1945 s A. Bendou; ibid., Protokol sepsaný 16. 10. 1945 s Kateřinou Birnbaumovou.

110 Ibid., Protokol ze dne 18. 10. 1945. NSV - Nationalsozialistische Volkswohlfahrt, organizace sociální péče přidružená $\mathrm{k}$ NSDAP.

111 Ibid., Opis rozhodnutí čj. 15410-VIII, 28-45, srov. č. j. 2381/47, ze dne 27. 9. 1947.

112 SOkA Jihlava, fond MNV Puklice, Kniha 1, Zápisy ze schůzí pléna MNV, Zápis o schůzi z 26. 10. 1945, s. 164.

113 Viz SOkA Jihlava, fond MNV Puklice, Kniha 1, Zápisy ze schůzí pléna MNV, s. 338.

114 Ibid., Spisy, inv. č. 49, Věci stavební, Půdorys provozovny v traktu budovy č. 1.

115 Ibid., Spisy, inv. č. 73, Konfiskáty, Národní správa, Dopis ze dne 2. 12. 1946; ibid., Kniha 1, s. $194,199$. K přidělení zámku: ibid., Dopis Národního pozemkového fondu z 2. 8. 1949.

116 Viz SOkA Jihlava, fond MNV Puklice, Likvidace nár. správy velkostatku v Puklicích, Zápis o služební cestě 11. 7. 1946; ibid., Kniha 1, Zápisy ze schůzí pléna MNV, s. 145. Zápis z 8. 8. 1945.

117 SOkA Jihlava, fond JNV Jihlava, inv. č. 133, Konfiskáty, Žádost o přidělení koupací vany z 8. 12.1946. 
památkové správy odvezen pravděpodobně poslední cenný inventář: dva obrazy alpské krajiny ve zlacených rámech a pianino. ${ }^{118}$

Mezi jednotlivce rozparcelovaná půda velkostatku se později zase zceluje v JZD Puklice, Př́seka a Studénky, z nichž v roce 1961 vzniklo JZD 25. února, to je však již jiná historie. Poslední majitel velkostatku se na několik dalších desetiletí stal pro všechny Němcem.

\section{Závěr}

V předloženém textu jsem se pokusil sledovat možné př́ičiny, průběh i odůvodnění konfiskace majetku židovského majitele velkostatku a zámku Puklice Richarda Fischmanna. Jak vyplývá z předchozího, Fischmann byl pravděpodobně především podnikatelem a i když ve svém způsobu řízení velkostatku nejednal nezákonně či nelidsky, nebyl patrně k Puklicím a Puklickým prŕliš ohleduplný. To samozřejmě nevyvolávalo sympatie a spolu s faktem, že Fischmann se svou rodinou v Puklicích nežil, to jen podporovalo touhu obce, naplnit všechna přání, jejichž neprovedení si vyčítala od vzniku Československa. Již ve dvacátých letech se pisatel místní kroniky Josef Šuhaj ptá, proč obec právem národní revoluce zámek a statek nezabrala, ${ }^{119}$ situace po roce 1945 obci splnění tohoto přání prríhodně umožnila. Nenávist proti poslednímu majiteli velkostatku, která se po skončení války zdvihla, sice neměla vnější podobu antisemitismu a protižidovských stereotypů, nebyla však o nic méně nacionálně orientovaná. Fischmann byl účelově vykreslen nejen jako germanizátor, ale rovnou jako Němec a konfiskace jeho majetku tak měla budit dojem nápravy staletých křivd páchaných na Češích.

Historička Helena Krejčová popsala konfiskace židovského majetku v roce 1945 jako předzvěst února $1948^{120}$ a na puklický př́pad se takový popis jistě hodí. Účelově vytvořená, a v průběhu následujících desetiletí upevněná představa o Fischmannově němectví vedla k neobyčejně silnému přesvědčení, že konfiskace byla správná. Nepřekvapí proto dohra po roce 1989, kdy se podruhé vdaná Fischmannova dcera Eliška Fabryová o svůj restituční nárok přihlásila. Následný kolotoč žalob, rozsudků a zrušených rozhodnutí není sice předmětem této práce, ${ }^{121}$ ale alespoň heslovitě: Požadavek Fabryové byl nejprve odmítnut, protože svou stížnost na nespravedlivě projednané zabavení majetku podala po více než pěti letech od konfiskace, následně jí byla restituce odepřena, jelikož Richardu Fischmannovi nebylo navráceno české občanství (nikdy jej totiž neztratil). Obec Puklice i Sokol navíc stále trvaly na velkostatkářově němectví a oprávněnosti konfiskace z let 1945-1947. Jako diskriminací ze strany České republiky - která v roce 1994 rozhodla, že židovský zemědělský majetek nebude navracen, aby se nemuselo znovu vyvlastňovat (neoprávněným) restituentům - se př́padem dokonce zabýval výbor pro lidská práva OSN. Teprve v lednu 2012 rozhodl soud, že Fischmann nikdy nepřestal být československým občanem a že konfiskace byla zneužitím dekretu č. 108/1945, protože byl vztažen na obět nikoliv na představitele nacismu.

\footnotetext{
118 SOkA Jihlava, fond JNV Jihlava, inv. č. 132, Velkostatek Fischmann, karton 33, Eliminační seznam ze 14. 12. 1953.

119 SOkA Jihlava, Neinventarizovaný fond, Kronika obce Puklice, I., s. 34, podobně i s. 23.

120 [Krejčová 1992].

121 Blíže k němu viz Čermáková [2008], Mareš [2012; 2013].
} 
I když dekret prezidenta republiky 12/1945 Sb. nenařizoval konfiskaci židovského majetku (taková situace byla právně nepřípustná), $\mathrm{k}$ jeho konfiskaci $\mathrm{v}$ mnoha př́padech došlo pod rouškou obvinění z asociálního chování či germanizace. Puklický případ je případem závisti a nenávisti, jež se zakládají na majetkových rozdílech. ${ }^{122}$ Jak bylo řečeno v úvodu, nejedná se ani o jediný, ani o největší případ svého druhu, poměrně pregnantně však ukazuje nálady v poválečném Československu i dlouhý život účelově vytvořené propagandy a falešných obvinění.

\section{Prameny - Archivní fondy}

Moravský zemský archiv (MZA) v Brně, fond D9, Stabilní katastr - indikační skici (1824-1931).

MZA v Brně, fond F379, Velkostatek Puklice 1770-1938.

MZA v Brně, fond H 1211, Družstevní lihovar Brtnice.

MZA v Brně, fond H1235, Družstevní lihovar Puklice.

MZA v Brně, fond H1263, Družstevní lihovar Želetava.

Státní okresní archiv (SOkA) Jihlava, fond Jednotný národní výbor (JNV) Jihlava.

SOkA Jihlava, fond Místní národní výbor (MNV) Puklice.

SOkA Jihlava, fond Obecní úrad Puklice.

SOkA Jihlava, Neinventarizovaný fond, Kronika obce Puklice.

\section{Literatura}

Čapková, Kateřina [2005]. Češti, Němci, Židé? Praha - Litomyšl: Paseka.

Čermáková, Radka [2009]. Poválečné Československo. Obnovený stát ve stř̌ední Evropě. In. Židovská menšina v Československu po druhé světové válce. Od osvobození k nové totalitě. Praha: Židovské muzeum v Praze, s. 23-35.

Čermáková, Silvie [2008]. Vlastivědný sborník Vysočiny. Oddíl věd společenských. Svazek 16, ročník 2008, s. $285-288$.

Dvorský, František [1906]. Vlastivěda moravská. Třebický okres. Brno: Musejní spolek.

Hoffmann, František - Jaroš, Zdeněk - Pisková, Renata - Svěrák, Vlastimil [2000]. Jihlava. Historickýatlas měst České republiky. Praha: Historický ústav Akademie věd České republiky.

Jančík, Drahomír - Kubů, Eduard - Kuklík, Jan [2003]. „Arizace“ a restituce židovského majetku v českých zemích (1939-2000). Praha: Ústav hospodářských a sociálních dějin FF UK.

Jaroš, Zdeněk [1994]. Mladý Gustav Mahler a Jihlava. Jihlava: Muzeum Vysočiny.

Jaroš, Zdeněk [1998a]. Nejstarší historie Židů na Jihlavsku. In. Kolektiv autorů. Dotyky. Sborník k výstavě. Jihlava: Muzeum Vysočiny, s. 9-23.

Jaroš, Zdeněk [1998b]. Několik poznámek k novodobé historii jihlavských Židů. In. Kolektiv autorů. Dotyky. Sborník k výstavě. Jihlava: Muzeum Vysočiny, s. 30-35.

Jaroš, Zdeněk [2004]. Puklice, Neznámé známé Jihlavsko - zastavení 23. Jihlavské listy 15 (102): 18.

Jaroš, Zdeněk - Zimola, David [1998]. Židé z Jihlavska v transportech Av a Aw. Kolektiv autorů. Dotyky. Sborník k výstavě. Jihlava: Muzeum Vysočiny, s. 151-2007.

Krejčová, Helena [1992]. Čechy na úsvitu nové doby: český antisemitizmus 1945-1948. In. Antisemitizmus $v$ posttotalitní Evropě. Sborník z Mezinárodního semináře. Praha: Společnost Franze Kafky, s. 103-110.

Mareš, Miroslav [2012]. Dlouhé puklické restituce: desetiletý spor o zámek pokračuje. Jihlavské listy 24 (1): 3 .

Mareš, Miroslav [2013]. Soud: Zámek v Puklicích se má vrátit. Jihlavské listy 24 (29): 17.

Miller, Michael L. [2015]. Moravští Židé v době emancipace. Praha: NLN.

Novák, Jaromír [1989]. Historie obcí Puklice - Studénky - Petrovice. Jihlava: MNV Puklice.

${ }^{122}$ Lze též mluvit o ekonomickém antisemitismu. 
Pátek, Alois. [1901]. Vlastivěda moravská. Jihlavský okres. Brno: Musejní spolek.

Pěkný, Tomáš [2001]. Historie Židi̊ v Čechách a na Moravě. Praha: Sefer.

Peroutková, Michaela [2016]. Židovské identity v Československu pred 2. světovou válkou a po ní. Praha: Libri.

Petráš, René [2009]. Menšiny v poválečném Československu. Právní postavení národnostních menšin v první Československé republice a jejich mezinárodněprávní ochrana. Praha: Karolinum.

Pisková, Renata, a kol. [2009]. Jihlava. Praha: NLN.

Scheinhammer-Schmid, Ulrich (ed.) [2013]. Einführung in den Band. Str. 22-64 In: „In Iglau war alles schlimmer..." „,V Jihlavě bylo všechno horší". Landsberg am Lech: Balaena.

Soukupová, Blanka [2009]. Židé a židovská reprezentace v Českých zemích v letech 1945-1948 (Mezi režimem, židovství a judaismem). In. Židovská menšina v Československu po druhé světové válce. Od osvobození $k$ nové totalitě. Praha: Židovské muzeum v Praze, s. 55-80.

Staněk, Tomáš [1991]. Němečtí Židé v Československu 1945-1948. Dějiny a současnost 13 (5): 42-46.

Svěrák, Vlastimil [1998]. Židovská náboženská obec v Puklicích. In. Kolektiv autorů. Dotyky. Sborník $k$ výstavě. Jihlava: Muzeum Vysočiny, s. 91-94.

Šimka, Alois [1958]. Národně osvobozenecký boj na Jihlavsku. Brno: Krajské nakladatelství v Brně.

Vilímek, Ladislav [2016]. I domy umírají vstoje III. Jihlava: Statutární město Jihlava.

Vrána, Filip [2010]. Pivovary na Vysočině 3. Puklice. Jihlavské listy 21 (57): 12.

\section{Internetové zdroje}

Vilímek, Ladislav. Sága rodu Fischmannů. Dostupné z: <http://www.regionalist.cz/vilimek/vil01_36.htm> [25. 8. 2018].

Vilímek, Ladislav. Puklice. Dostupné z: <http://www.regionalist.cz/vilimek/vil01_2.htm> [25. 8. 2018].

Stránky obce Puklice. Dostupné z: <http://mujweb.cz/puklice> [25. 8. 2018].

The United States Holocaust Memorial Museum; Holocaust Survivors and Victims Database. Dostupné z: $<$ https://www.ushmm.org/online/hsv/person_view.php?PersonId=6880153> [25. 8. 2018].

Jan Koumar $\left({ }^{*} 1978\right)$ absolvoval studium Historické sociologie na Fakultě humanitních studií UK, kde v současné době studuje doktorský obor Aplikovaná etika. Zabývá se sociologií a etikou každodennosti, dále pak regionálními dějinami Jihlavska. 